\title{
Mineral chemistry of some agates from Gurasada (Mureş Valley, Romania)
}

\author{
Ovidiu Gabriel IANCU1, Dorel Petru TODA² \& Gabriela IANCU³ \\ 1 “Alexandru Ioan Cuza” University, Department of Geology, RO-700505 Iaşi, Romania \\ ${ }^{2}$ Mineral Toda S.R.L., Crişcior, RO-337200, Romania \\ 3 „Otilia Cazimir” School, Iaşi, RO-700505, Romania
}

Received February 2009; accepted April 2009

Available online June 2009

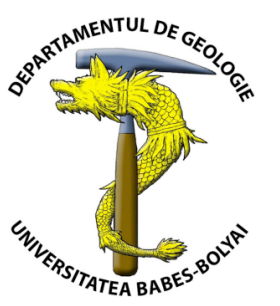

ABSTRACT. The paper presents the study of some agates from the Gurasada area (Mureş Valley, West Romania) and their igneous host rocks. Agates occur in the vesicles of strongly altered pyroclastic rocks ("banatites"), such as basaltic andesites, trachyandesites, trachytes and dacites or in the alluvial sediments along the Gurasada valley. The age of host-rocks is Late Cretaceous-Early Paleogene. Agates consist mainly of various types of $\alpha$-quartz such as: chalcedony, quartzine and microquartz, associated with moganite. The genesis of agates is related with the hydrothermal solutions which altered the host-rocks.

Key words: agates, microtexture, volcanics, Late Cretaceous-Early Paleogene, banatites, Mureş Valley.

\section{INTRODUCTION}

The Mureş Zone of the Southern Apuseni Mountains (Romania) consists mainly (Anđelković and Lupu, 1967; Saccani et al., 2001; Bortolotti et al., 2002) of Middle to Late Jurassic ophiolites and associated island arc volcanics and Cretaceous Wildflysch sediments (Fig. 1). Late Cretaceous-Early Paleogene magmatites assigned to socalled banatites, occur in places. In the surroundings of the town of Gurasada (W of the city of Deva) in the banatitic pyroclastic rocks and in the alluvial sediments of the Gurasada River, various agates are found. The aim of this paper is a geological, mineralogical and geochemical study of these agates and their host-rocks.

\section{SAMPLES AND METHODS}

A number of 30 samples of volcanics and agates from the Gurasada area were collected, and documented. Out of all, 8 samples (4 volcanics and 4 agates from the same rocks) were analyzed for major elements. Thin sections were prepared at the Department of Mineralogical and Petrological Sciences, at the University of Turin, Italy. The thin sections were studied first under transmitted and reflected polarized light with an Olympus BX 60 optical microscope equipped with a JVC 3-CCD Colour Video Camera. After coating with carbon, the thin sections were investigated with a Cambridge Stereoscan 360 SEM equipped with an EDS Energy 200 and a Pentafet detector (Oxford Instruments) at the Department of Mineralogical and Petrological Sciences, University of Turin, Italy. The operating conditions were: $50 \mathrm{~s}$ counting time, $15 \mathrm{kV}$ accelerating voltage and 2.70-2.80 A beam current. The SEM-EDS quantitative data (spot size $=2 \mu \mathrm{m}$ ) were acquired and processed using the Microanalysis Suite Issue 12, INCA Suite version 4.01 software. The raw data were calibrated on natural mineral standards and the $\phi \rho \mathrm{Z}$ correction (Pouchou and Pichoir, 1988) was applied.

Wet-chemical analyses of the agate-bearing volcanics were carried out at Prospectiuni S.A. Bucharest using a set of standard methods for quantitative analysis (gravimetry, colorimetry and absorption spectrometry) following the techniques recommended by Maxwell (1968) and Iosof and Neacşu (1980). The Penfield method was used for water determination.

For measuring the agate toughness, the cylinder splitting test known as the Brazilian test, was applied. The Brazilian test is well adapted for the measurement of toughness and the characterization of the BDT (brittle to ductile transition) of materials which are brittle at room temperature. The test was carried on at the University of Manchester, Great Britain, with a simple motor-driven press, by applying compressive forces on two opposite generatrix of a cylinder. This has caused an uniform tensile stress on the plane containing the axis of the cylinder and the generatrix, leading to mode I cracking.

\section{GEOLOGICAL SETTING}

According to Rădulescu and Dimitrescu (1982), north of the Mureş River on the southern border of the Apuseni Mountains, as well south of the Mureş Valley close to the Southern Carpathians, intermediate to acid volcanics occur, within the ophiolitic zone or south of it. The most representative rocks are: basaltic andesites, biotite and hornblende andesites, hornblende andesites, quartz andesites with hornblende and pyroxenes, pyroxene andesites, 
trachyandesites, trachytes and dacites. They form either lava flows and subvolcanic intrusions or pyroclastic flows. Until 1983, several authors, e.g. Kadič (1906), Papiu (1954), Savu (1962), Peltz and Peltz (1965), Ghiţulescu and Borcoş (1966), Rădulescu and Borcoş (1968), Ianovici et al. (1969), Popescu (1983, 1984, fide Borcoş et al., 1986) regarded these rocks as Neogene in age. The general opinion has changed since 1983, when Popescu (fide Borcoş et al., 1986) identified in the area SE of Gurasada, in the sediments associated with the volcanics, a Late Cretaceous-Early
Paleogene microfauna. Savu et al. (1984, unpublished data) established a radiometric age of $59.6 \pm 2.4 \mathrm{Ma}$ (i.e., Paleocene) for a biotitic tuff and thus considered the volcanics as products of the banatitic magmatic event (Savu, 1984). Based on K-Ar data, Constantina (2008) established a Late Cretaceous age for the pyroclastic rocks from Gurasada. Like the similar magmatites from Banat their genesis is related to the subduction of a Late CretaceousEarly Paleogene ocean and the volcanics reflect a continental island arc setting (Savu et al., 1992).
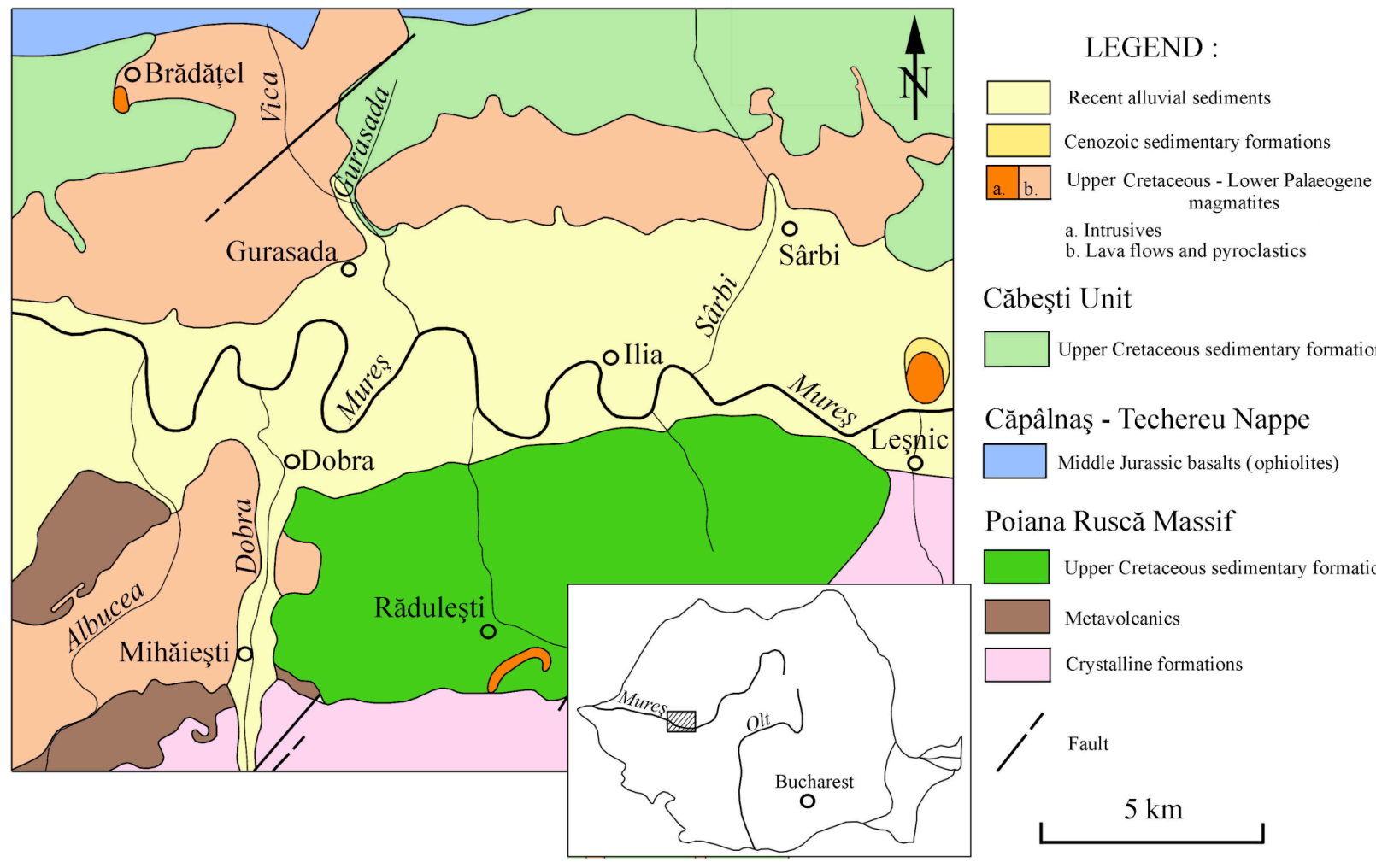

Căbești Unit
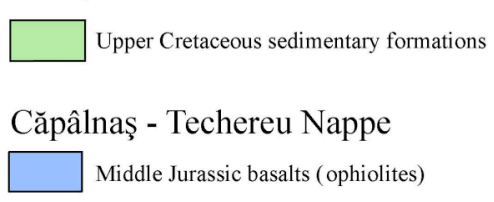

Poiana Ruscă Massif

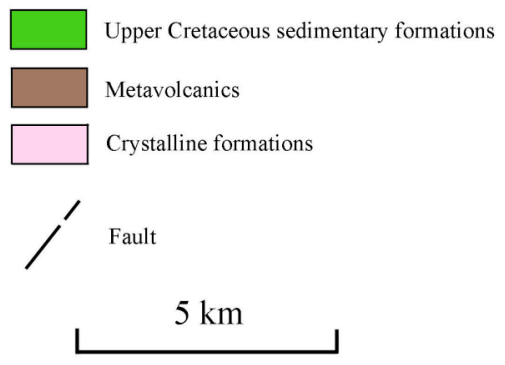

Fig. 1. Map of the Gurasada area (simplified after the Geological Map of Romania, 1:50.000; Gurasada Sheet; Lupu et al., 1986).

\section{OCCURRENCES}

The agates occur sporadically over the whole area, in the vesicles of strongly altered pyroclastic rocks (banatites), such as basaltic andesites, trachyandesites, trachytes and dacites, but mainly west of the Gurasada brook. Agates can also be found in the alluvial sediments of the Vica, Sârbi and Cărmăzîneşti brooks (Fig. 1). The separation of the host-rocks has been done based on petrographical and geochemical data (Table 1). The $\mathrm{SiO}_{2}$ content varies between 56.78 and 67.77 wt.\%, higher in trachytes and lower in basaltic andesites. $\mathrm{Al}_{2} \mathrm{O}_{3}$ content is generally near 15-16 wt.\%, a bit higher in trachyandesites. $\mathrm{Fe}_{2} \mathrm{O}_{3}$ is higher in dacites (around 4.50 wt.\%) and lower in tracyhtes. $\mathrm{FeO}$ and $\mathrm{MgO}$ are generally low in dacites and trachytes. $\mathrm{Na}_{2} \mathrm{O}$ and $\mathrm{K}_{2} \mathrm{O}$ are generaly less than 5 wt.\%. An important difference can be noticed in the $\mathrm{CaO}$, which is higher in basaltic andesites and lower in trachytes.

\section{MINERALOGICAL DATA}

Gurasada agates are often large, up to $15-25 \mathrm{~cm}$ in diameter. Together with agates, in the Gurasada area usually various chalcedony, jasper, petrified wood (Fig. 2), opal, quartz, amethyst, zeolites, celadonite, calcite, siderite, pyrite, marcasite, goethite and hematite may occur. Celadonite forms frequently the green cover that surrounds the agates. Several textural types of agates were identified: (1) brecciated agates (Fig. 3), (2) carnelian agates, (3) concentric (wall-layered) agates (Fig. 4), (4) moss agates, (5) tubular agates and (6) vein agates. They are characteristically coloured in shades of yellow-brown or bluish-grey. The characteristic features clearly visible in cut or broken agates are: the "skin", concentric layers of lengthfast fibrous chalcedony, an inner layer of coarse length-slow quartz crystals and a centre of large quartz crystals (Fig. 5). Some agates show the so-called structure "escape tube", which indicates that chalcedony or quartz has undergone deformation just before crystallization. This structure is often associated with a balloon-shaped structure called "dilatation on the escape tube" and with a crack in the clear chalcedony layer which in turn leads directly to a small mark on the exterior of the agate called "agate dyke" (Macpherson, 1989).

According to Moxon and Reed (2006), most of agates consists of a mixture of two silica polymorphs: $\alpha$-quartz and moganite. Among the quartz structural types, the length-fast chalcedony (chalcedony s.s.), quartzine (also called lengthslow chalcedony), pseudochalcedony and microquartz are the most common. The crystal structure of moganite 
(formerly "lutecite") has been described as the alternate stacking of layers of left- and right-handed quartz at the unit-cell scale (Miehe and Graetsch, 1992).

Table 1. Chemical composition of some agate-bearing volcanic rocks from Gurasada. Abbreviations: GS1-basaltic andesite; GS10 - trachyandesite; GS11-dacite; GS13 - trachyte.

\begin{tabular}{|c|c|c|c|c|}
\hline \multirow{2}{*}{$\begin{array}{c}\text { OXIDES } \\
(\mathrm{wt} \%)\end{array}$} & \multicolumn{4}{|c|}{ Samples } \\
\hline & GS1 & GS10 & GS11 & GS13 \\
\hline $\mathrm{SiO}_{2}$ & 56.78 & 58.84 & 65.63 & 67.77 \\
\hline & 0.82 & 0.55 & 0.50 & 0.77 \\
\hline $\mathrm{Al}_{2} \mathrm{O}_{3}$ & 15.94 & 16.18 & 15.47 & 15.22 \\
\hline $\mathrm{Fe}_{2} \mathrm{O}_{3}$ & 3.90 & 2.98 & 4.56 & 1.77 \\
\hline Fe & 3.3 & 2. & 0 & .54 \\
\hline $\mathrm{MnO}$ & 0.15 & 0.0 & 0.0 & 0.03 \\
\hline $\mathrm{MgO}$ & 4.56 & 3.54 & 0.74 & 0.68 \\
\hline & 703 & 6.51 & 4.9 & 1.78 \\
\hline $\mathrm{Na}_{2} \mathrm{O}$ & 2.2 & 4.0 & 2.6 & 5.01 \\
\hline $\mathrm{K}_{2} \mathrm{O}$ & 2.70 & 2.34 & 3.16 & 3.86 \\
\hline $\mathrm{P}_{2} \mathrm{O}_{5}$ & 0.31 & 0.21 & 0.26 & 0.20 \\
\hline $\mathrm{CO}_{2}$ & - & 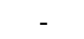 & - & 0.89 \\
\hline $\mathrm{S}$ & 0.10 & - & 0,18 & 0.08 \\
\hline $\mathrm{H}_{2} \mathrm{O}^{+}$ & 2.06 & 2.33 & 1.51 & 1.32 \\
\hline Total & 99.94 & 99.96 & 99.95 & 99.92 \\
\hline
\end{tabular}

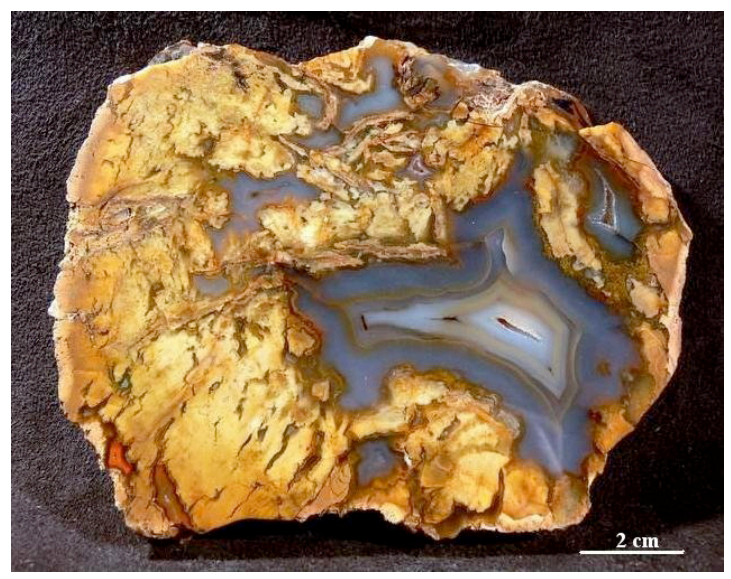

Fig. 2. Petrified wood from Gurasada.

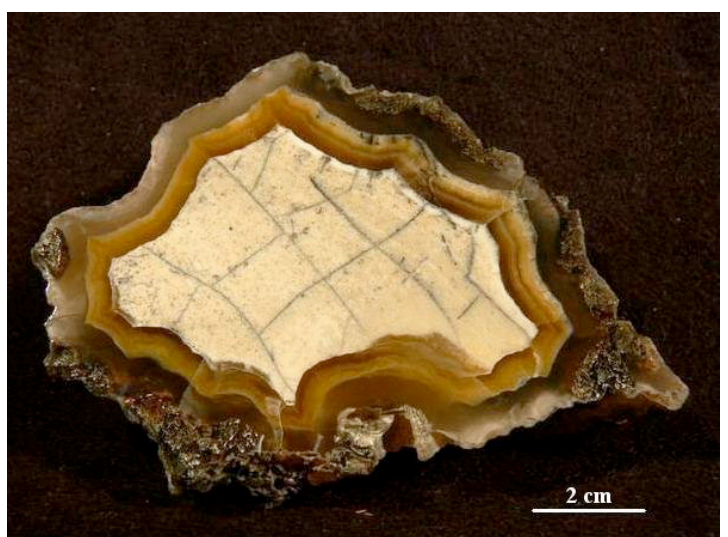

Fig. 3. Brecciated agate from Gurasada.

The typical texture of agates observed under the polarized light microscope is the fibrosity, usually formed after the crystallization has started from small spherulites. The main textures observed in the Gurasada agates are the long fibres, the spherulites and the block system (acc. to classification of Moxon, 1996; Fig. 6). Approximately $60 \%$ of the inner area is composed of typical chalcedonic quartz, i.e. the fibrousgrown type (Fig. 6a). It frequently takes over from the sheaflike forms type (Fig. 6b) and sweeps towards the centre.

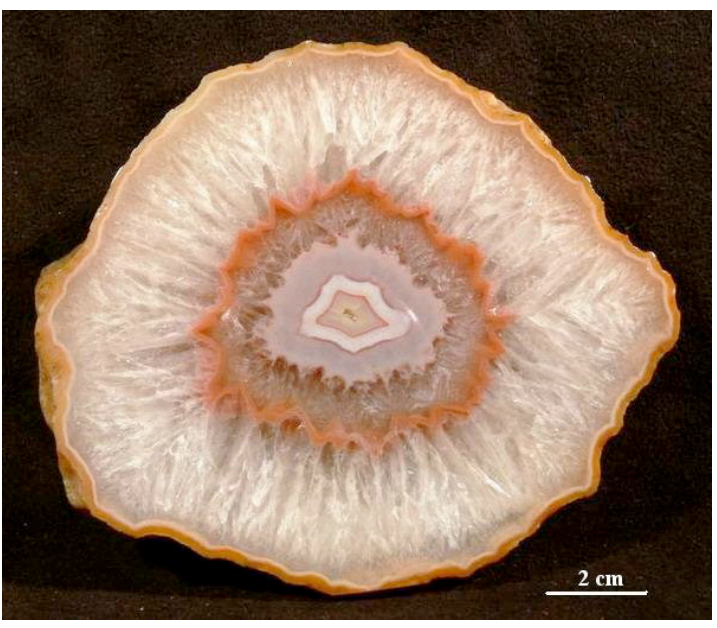

Fig. 4. Concentric agate from Gurasada.

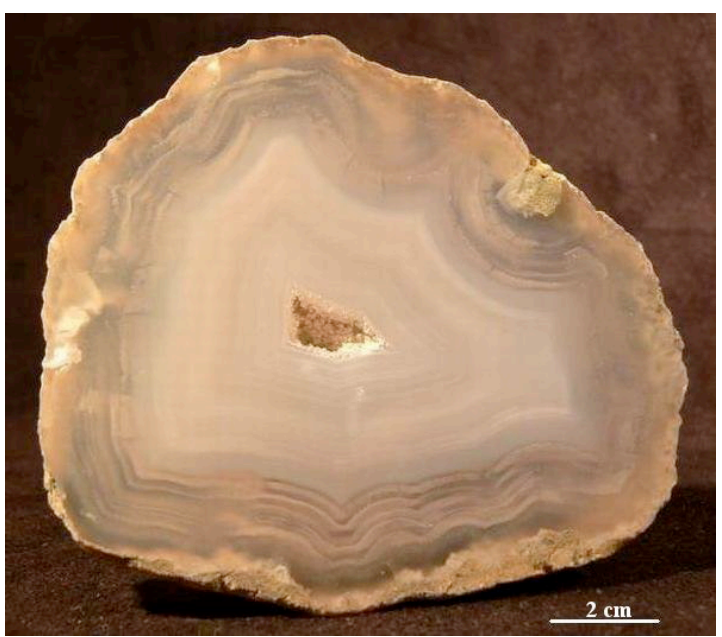

Fig. 5. Large quartz crystals in the center of a concentric agate from Gurasada.

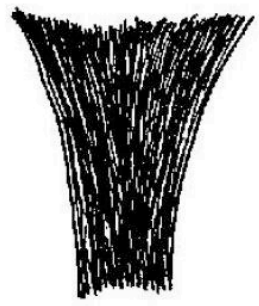

a)

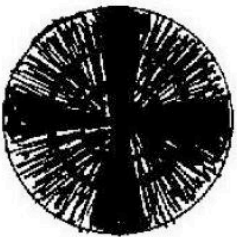

c)

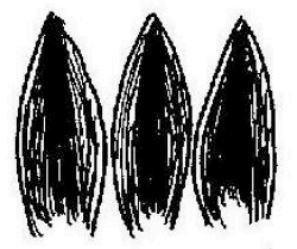

b)

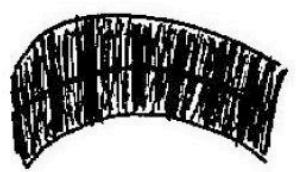

d)
Fig. 6. Microtextures of agates as observed in polarized light (Moxon, 1996).

In the concentric (banded) agates, the length-fast chalcedony fibres radiate towards the centre of the geode from many nucleation points located on the wall surface, and form parabolic fibre bundles. The interference of the neighbouring bundles results in a parallel/concentric texture. Between crossed polars, the wall-lining chalcedony exhibits rhythmic extinction showing bands normal to the direction 
of the fibres elongation (Graetsch, 1994). Quartz crystals are usually found in the centre of the agates.

According to Pop et al. (2004) all gem-quality $\mathrm{SiO}_{2}$ varieties, including the ,amorphous" ones (opals, silicified wood) from Gurasada, may contain moganite in variable amounts (from traces up to 75 wt.\%). No correlation between the colour of the gem material and the mineralogical composition has been found so far.

Due to its compact microstructure, agate is exceptionally hard. The Brazilian test of an agate fom Gurasada revealed a high value of $23.85 \mathrm{MPa}$ for the tensile strength at failure (the resistance of a material to a force tending to tear it apart, measured as the maximum tension the material can withstand without tearing) which was caused by a force of $16.79 \mathrm{kN}$ (Fig. 7).

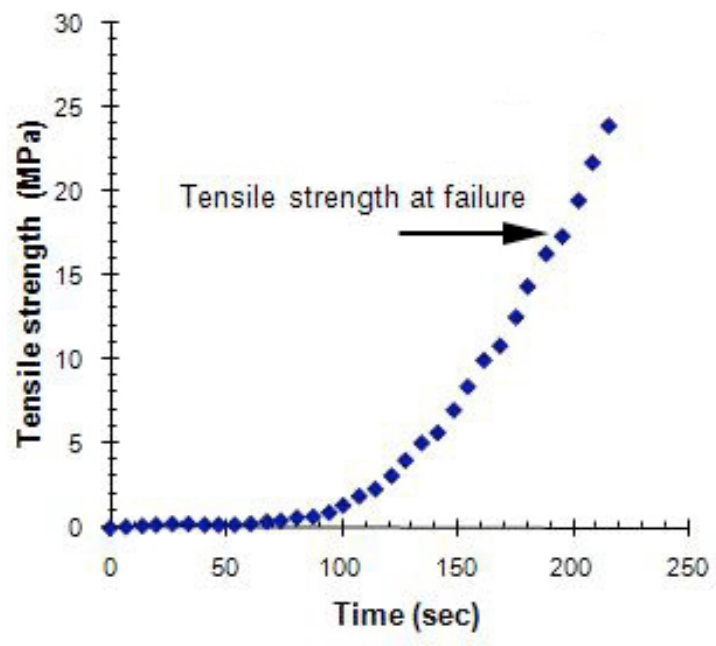

Fig. 7. The tensile strength at failure for an agate from Gurasada.

\section{MINERAL-CHEMISTRY}

The chemical analyses of 4 agate samples (Table 2) done by a combined JEOL 6400 scanning electron microscope (SEM) with EDS at the University of Manchester, England, show high values of $\mathrm{SiO}_{2}(95.87-99.20$ wt.\%) and minor amounts of $\mathrm{Al}_{2} \mathrm{O}_{3} \quad\left(0.10-1.30\right.$ wt.\%), $\mathrm{Fe}_{2} \mathrm{O}_{3} \quad(0.20-1.45$ wt.\%), $\mathrm{CaO}$ (0.05-0.56 wt.\%), $\mathrm{MgO}$ (0.00-0.16 wt.\%), $\mathrm{Na}_{2} \mathrm{O}$ (0.03-0.25 wt.\%), $\mathrm{K}_{2} \mathrm{O}$ (0.00-0.16 wt.\%). The $\mathrm{Al}_{2} \mathrm{O}_{3}, \mathrm{TiO}_{2}$, $\mathrm{Fe}_{2} \mathrm{O}_{3}, \mathrm{MgO}$, and $\mathrm{CaO}$ contents are higher in agates occurring in basaltic andesites. With values up to $2.06 \mathrm{wt} . \%$, the water content is slightly above the $1.5 \mathrm{wt} \%$ value of Miehe and Graetsch (1992). According to Moxon and Rios (2004), the molecular (free) water was found to be independent of age but maturation produced a general decrease in both the moganite and internal water. The same authors stated that internal water is involved on the transformation of moganite into chalcedony and this change is responsible for an internal growth in chalcedony crystallites.

The large quartz crystals in the centre of the agates contain much less iron, aluminum, calcium etc. than the surrounding layers. Thus, most likelythey grew from more pure solutions than those which contained the silica gels from which, the fibrous chalcedony was diagenetically formed.
Table 2. Selected EDS analyses (recalculated to 100\%) of some agate samples from Gurasada. Abbreviations: AGS1 - agate from basaltic andesites; AGS10 - agate from trachyandesites; AGS11 - agate from dacites; AGS13 - agate from trachytes.

\begin{tabular}{c|ccccc}
\hline \multirow{2}{*}{$\begin{array}{c}\text { Oxides } \\
\text { (wt\%) }\end{array}$} & \multicolumn{5}{|c}{ Samples } \\
\cline { 2 - 5 } $\mathrm{SiO}_{2}$ & AGS1 & $\mathbf{A G S 1 0}$ & $\mathbf{A G S 1 1}$ & $\mathbf{A G S 1 3}$ \\
$\mathrm{TiO}_{2}$ & 0.40 & 98.08 & 98.49 & 99.20 \\
$\mathrm{Al}_{2} \mathrm{O}_{3}$ & 1.30 & 0.11 & 0.07 & 0.00 \\
$\mathrm{Fe}_{2} \mathrm{O}_{3}$ & 1.45 & 0.65 & 0.57 & 0.10 \\
$\mathrm{MgO}$ & 0.16 & 0.43 & 0.29 & 0.20 \\
$\mathrm{CaO}$ & 0.56 & 0.07 & 0.02 & 0.00 \\
$\mathrm{Na} 2 \mathrm{O}$ & 0.03 & 0.38 & 0.24 & 0.05 \\
$\mathrm{~K}_{2} \mathrm{O}$ & 0.00 & 0.05 & 0.12 & 0.25 \\
$\mathrm{SO}_{3}$ & 0.23 & 0.18 & 0.12 & 0.16 \\
\hline $\mathrm{Total}$ & 100.00 & 100.00 & 0.08 & 0.04 \\
\hline
\end{tabular}

\section{DISCUSSIONS CONCERNING THE GENESIS OF AGATES}

Recent isotopic research (Harder, 1994) suggests that agates form at low temperatures, around $100^{\circ} \mathrm{C}$ as byproduct of the clay mineral genesis, upon the complete cooling and the burial of the volcanics to a depth of 100 to 200 meters. According to the same author, during the weathering process of the volcanic rocks, Fe-rich clay minerals such as celadonite or delessite, usually found in the green crust of the agates, occur and the remaining $\mathrm{SiO}_{2}$-rich colloidal solutions fill in the voids of the rock, i.e. vesicles. The geochemical study of Götze et al. (2001) demonstrated that the formation of agate can be a complex, multi-steps process which takes place during the formation and alteration of the parental volcanic rock. The trace element and the isotope data lead to the conclusion that the $\mathrm{SiO}_{2}$ necessary for the agate formation is mobilized during the alteration of the volcanics by own hydrothermal solutions (auto-metasomatosis). We agree with the idea proposed by Moxon and Rios (2004) that hydrothermal solutions are the source of the silica in all cases of agate genesis in an igneous environment.

\section{CONCLUSIONS}

The main types of agates from the Gurasada area can be separated as follows: brecciated agates, carnelian agates, concentric (wall-layered) agates, moss agates, tubular agates and vein agates. The main textures observed in the Gurasada agates are the long fibres, the spherulites and the block system (acc. to classification of Moxon, 1996). The chemical analyses show some slight differences regarding the $\mathrm{SiO}_{2}$ content (lower in agates from basaltic andesites) and the $\mathrm{Al}_{2} \mathrm{O}_{3}, \mathrm{Fe}_{2} \mathrm{O}_{3}, \mathrm{MgO}$ and $\mathrm{CaO}$ contents (higher in agates from basaltic andesites). No correlation between the water and moganite contents has been found so far. More detailed techniques are needed in order to estimate the genesis of the agates from the investigated area.

Acknowledgments. We are deeply grateful to Prof. Dr. Roberto Compagnoni from the University of Turin, Italy and to Prof. Dr. Ernie Rutter from the University of Manchester, Great Britain, for their assistance and hospitality in their laboratories. We also thank Liliana Irimia from Prospecțiuni S.A. Bucharest for wet-chemical analyses of the agatebearing volcanics. Careful and constructive comments and suggestions from Profs. Volker Hoeck and Corina Ionescu that significantly improved the article are greatly appreciated. 


\section{R E F E R E N C E S}

Anđelković, M.Z., Lupu, M. 1967, Die geologie der Šumadija- und Mureş- zone: stratigraphische gliederung, fazies, magmatismus, tektonik. Carpatho-Balkan Geological Association VIII Congress, Belgrade, Reports, Geotectonics, p. 15-28.

Borcoş, M., Popescu, Gh. \& Roşu, E. 1986, Nouvelles données sur la stratigraphie et l'evolution du volcanisme tertiare des Monts Métallifères. Dări de Seamă ale Institutului de Geologie şi Geofizică, 7071 (4): 245-259.

Bortolotti, V., Marroni, M., Nicolae, I., Pandolfi, L., Principi, G. \& Saccani, E. 2002, Geodynamic implications of Jurassic ophiolites associated with Island-Arc Volcanics, South Apuseni Mountains, Western Romania. International Geological Review 44: 938-955.

Constantina, C. 2008, The study of the Paleocene volcanoclastic complex from the Sârbi-GurasadaBurjuc region (Mureş Valey), concerning the minerals with gemological value. $\mathrm{Ph}$. D. Thesis, University Babeş-Bolyai, Cluj-Napoca, 135 p. (in Romanian).

Ghițulescu, T.P., Borcoş, M. 1966, Functional fraiming of the Alpine magmatism in the Metaliferi Mountains. Studii şi Cercetări de Geologie, Geofizică, Geografie, Seria Geologie, 10 (2): 267-279 (in Romanian).

Götze, J., Tichomirowa, M., Fuchs, H., Pilot, J. \& Sharp, Z.D. 2001, Geochemistry of agates: A trace element and stable isotope study. Chemical Geology, 175: 523-541.

Graetsch, H. 1994, Structural characteristics of opaline and microcrystalline silica minerals. Reviews in Mineralogy, 29: 209-232.

Harder, H. 1994, Achat als Nebenprodukt der Tonmineralbildung. Zeitschrift Deutsche Gemmologische Gesellschaft, 43: 19-37.

Ianovici, V., Giuşcă, D., Ghițulescu, T.P., Borcoş, M., Lupu, M., Bleahu, M. \& Savu, H. 1969, The geologic evolution of the Metaliferi Mountains. Ed. Academiei Bucureşti, 743 p. (in Romanian).

Iosof, V., Neacşu, V. 1980, Analysis of silicate rocks by atomic absorption spectrometry. Revue Roumaine de Chimie, 25: 589-597.

Kadič, O. 1906, Die geologischen Verhältnisse des Berglandes am linken Ufer der Maros in der Umgebung von Czela, Bulza and Poszoga. Jahre Ungarischen Geologischen Anstalt, p. 148-165.

Lupu, M., Peltz, S., Boştinescu, S., Roşu, E., Kräutner, H. G., Horvath, A., Mureşan, M., Mureşan, G., Bandrabur, T., Popescu, A. \& Nicolae, I. 1986, Geological Map of Romania sc. 1:50.000, Gurasada sheet. Geological Institute of Romania (in Romanian).

Macpherson, H.G. 1989, Agates. Natural History Museum Publications, London, $72 \mathrm{p}$.
Maxwell, J.A. 1968, Rock and Mineral Analysis. Interscience Publishers, London, 584 p.

Miehe, G., Graetsch, H. 1992, Crystal structure of moganite: a new structure type for silica. European Journal of Mineralogy, 4: 693-706.

Moxon, T.J. 1996, Agate microstructure and possible origin. Terra Publications, $106 \mathrm{p}$.

Moxon, T., Rios, S. 2004, Moganite and Water Content as a Function of Age in Agate: an XRD and Thermogravimetric Study. European Journal of Mineralogy, 16 (2): 269-278.

Moxon, T., Reed, S.J.B. 2006, Agate and chalcedony from igneous and sedimentary hosts aged from 13 to 3480 Ma: a cathodoluminescence study. Mineralogical Magazine, 70 (5): 485-498.

Papiu, V.C. 1954, Géologie de la région Valea MareCăprioara-Bulza-Pojoga. Comptes Rendus des Seances de l'Institut Geologiques de Roumanie, XXXVIII: 169-178.

Peltz, S., Peltz, M. 1965, Note on some occurences of crystalline schists from Tisa-Ioneasa region. Dări de Seamă ale Comitetului Geologic, LI (1): 109-116 (in Romanian).

Pop, D., Constantina, C., Tătar, D. \& Kieffer, W. 2004, Raman Spectroscopy on gem-quality microcrystalline and amorphous silica varieties from Romania. Studia Universitatis Babeş-Bolyai, Geologia, XLIX (1): 41-52.

Pouchou, J.L., Pichoir, F. 1988, Determination of mass absorption coefficients for soft X-rays by use of the electron microprobe. In Microbeam Analysis (Newbury, D.E., Ed.), San Francisco Press, p. 319-324.

Rădulescu, D., Borcoş, M. 1968, Aperçu général sur le déroulement du volcanisme néogène en Roumanie. Anuarul Comitetului de Stat al Geologiei, XXXVI: 177-193.

Rădulescu, D., Dimitrescu, R. 1982, Petrologia endogenă a teritoriului R. S. România. Univ. Bucureşti, 120 p. (in Romanian).

Saccani, E., Nicolae, I. \& Tassinari, R. 2001, Tectonomagmatic setting of the Jurassic ophiolites from the South Apuseni Mountains (Romania): petrological and geochemical evidence. Ofioliti, 26 (1): 9-22.

Savu, H. 1962, About the Neogene eruptions from the northern area of the Poiana Ruscă Massif. Dări de Seamă ale Comitetului Geologic, XLIII: 113-130 (in Romanian).

Savu, H. 1984, The melange with pyroclastic matrix associated with the southern island arc of the Mureş Valley. Studii şi Cercetări de Geologie, Geofizică, Geografie, Seria Geologie, 29: 36-43 (in Romanian).

Savu, H., Udrescu, C, Neacşu, V. \& Stoian, M. 1992, Petrology, geochemistry and origin of the Laramian volcanics of the Mureş couloir between Zam and Gurasada. Romanian Journal of Petrology, 75: 117-130. 